\title{
Excess of maternal HLA-DR3 antigens in HLA DR3,4 positive Type 1 (insulin-dependent) diabetic patients
}

\author{
I. Deschamps ${ }^{1}$, J.Hors ${ }^{2}$, F. Clerget-Darpoux ${ }^{3}$, E. Gardais ${ }^{1}$, J. J. Robert ${ }^{1}$, A. Marcelli-Berge ${ }^{4}$, H. Lestradet ${ }^{5}$ \\ and J. Dausset ${ }^{6}$ \\ ${ }^{1}$ INSERM U.30, Hôpital des Enfants Malades, ${ }^{2}$ U.93, Hôpital Saint Louis, ${ }^{3}$ U.155, Château de Longchamp, \\ ${ }^{4}$ Laboratoire de Sérologie et Histocompatibilité, Hôpital St.Louis, ${ }^{5}$ Hôpital Hérold and ${ }^{6}$ Collège de France, Paris France
}

\begin{abstract}
Summary. The susceptibility determinants of Type 1 (insulindependent) diabetes mellitus are known to be associated with both HLA-DR3 and DR4. In our study we wished to determine if the parental origin of these antigens could influence susceptibility to the disease. We analysed the inheritance of DR3 and DR4 haplotypes from the father or mother (DR3p, DR4p, DR3m and DR4m, respectively), in the index cases and in the affected and non-affected siblings of 246 diabetic simplex and 41 multiplex families without affected parents. An independent series of 80 multiplex families (GAW 5) was also studied. Among the DR3,4 positive index cases and affected siblings, the paternal and maternal DR3 and DR4 antigens were not distributed randomly: $62 \%$ and $72 \%$, respectively, had received DR4 from their father and DR3 from their mother (DR4p/DR3m), while only $38 \%$ and
\end{abstract}

$28 \%$, respectively, had received a paternal DR3 together with a maternal DR4 (DR3p/DR4m). This differed significantly from the $50 \%$ expected ratio $(p<0.01)$ and was not observed in unaffected siblings. No excess of maternal DR3 in the absence of DR4 and no excess of paternal DR4 in the absence of DR3 were observed. The finding suggests that some maternal DR3 related event (presumably during pregnancy) might play an enhancing role in the pathogenesis of Type 1 diabetes. It also implies that siblings with both DR4p and DR3m have a significantly higher risk for disease than those with DR3p and DR4m.

Key words: Type 1 (insulin-dependent) diabetes mellitus, HLA DR3, 4, shared haplotypes, segregation, multiple affected siblings, risk for siblings, maternal effect.
Susceptibility to Type 1 (insulin-dependent) diabetes mellitus is associated with the HLA antigens, DR3 and DR4 [1-4] in Caucasian populations. The risk for disease is greater in both unrelated subjects and in siblings of diabetic children [1-8] with a heterozygous DR3, DR4 phenotype. These observations have led to the hypothesis that two susceptibility genes associated with the DR3 and DR4 haplotype are involved in the inheritance of the disease $[2,9-13]$. Though, the exact nature of the molecule(s) responsible, and their role in the pathogenesis of the disease has not been elucidated, strong evidence suggests an autoimmune mechanism, probably triggered by environmental factors [14].

It has long been supposed that DR3 and DR4 associated susceptibility genes play different roles in the pathology of Type 1 diabetes, determining the clinical and genetic heterogeneity of the disease [15]. Recent data do indeed suggest that they probably do not have equivalent effects on susceptibility [16-18].

In this study we present evidence for the different effects of the paternal or maternal origin of DR3 and DR4 antigens on the risk for siblings of diabetic children.

\section{Subjects and methods}

Among 325 unrelated, Causasian French families of Type 1 diabetic patients who had been consecutively ascertained for HLA typing since 1978 (Herold series), 287 families were selected according to the following criteria: (1) unaffected parents with two or more offspring, of which at least one was diabetic; (2) availability of reliable information on the health status of all first degree relatives; (3) agreement of the families to participate in the study.

In 246 families, one single child was diabetic and in 41 families, two or more children were affected. The first affected child in each family was designated as the index case. Age at onset of Type 1 diabetes ranged from 1 to 18 years (mean 8.5 years) in index cases and the mean duration of follow-up from the date of diagnosis was 10.5 years. The severity of the disease was assessed by residual Cpeptide values and the presence/or absence of early complications. Ages of non-affected siblings at the time of the study ranged from 1 to 47 years (mean 19.5 years).

In order to compare samples of unrelated affected and unaffected siblings, a group of affected and a group of unaffected siblings were constituted by choosing one sibling from each family. The group of affected siblings included the second affected sibling in each multiplex family; the group of non-affected siblings included those siblings from each simplex family whose birth range preceded or, if impossible, followed that of the index case. How- 
Table 1. Frequencies of DR3, DR4 phenotypes and genotypes in index cases of Type 1 (insulin-dependent) diabetic multiplex and simplex families

\begin{tabular}{|c|c|c|c|c|c|c|c|}
\hline & \multirow[b]{3}{*}{ DR } & \multicolumn{4}{|c|}{ Herold series } & \multirow{2}{*}{\multicolumn{2}{|c|}{$\begin{array}{l}\text { Gaw } 5 \text { Series } \\
\text { Multiplex } \\
\text { families } \\
80\end{array}$}} \\
\hline & & \multicolumn{2}{|c|}{$\begin{array}{l}\text { Multiplex } \\
\text { families } \\
41\end{array}$} & \multicolumn{2}{|c|}{$\begin{array}{l}\text { Simplex } \\
\text { families } \\
246\end{array}$} & & \\
\hline & & $n$ & $(\%)$ & $n$ & $(\%)$ & $n$ & $(\%)$ \\
\hline $\begin{array}{l}\text { Pheno- } \\
\text { type }\end{array}$ & $\begin{array}{l}3 \\
4 \\
3,4 \\
x, x\end{array}$ & $\begin{array}{r}29 \\
28 \\
17 \\
1\end{array}$ & $\begin{array}{r}(71) \\
(68) \\
(41) \\
(2)\end{array}$ & $\begin{array}{r}139 \\
164 \\
81 \\
23\end{array}$ & $\begin{array}{r}(57) \\
(67) \\
(33) \\
(9)\end{array}$ & $\begin{array}{r}46 \\
63 \\
32 \\
3\end{array}$ & $\begin{array}{r}(58) \\
(79) \\
(40) \\
(4)\end{array}$ \\
\hline $\begin{array}{l}\text { Geno- } \\
\text { type }\end{array}$ & $\begin{array}{l}3 \mathrm{p} / 4 \mathrm{~m} \\
4 \mathrm{p} / 3 \mathrm{~m} \\
3 \mathrm{p} / \mathrm{xm} \\
\mathrm{xp} / 3 \mathrm{~m} \\
4 \mathrm{p} / \mathrm{xm} \\
\mathrm{xp} / 4 \mathrm{~m} \\
3 \mathrm{p} / 3 \mathrm{~m} \\
4 \mathrm{p} / 4 \mathrm{~m}\end{array}$ & $\begin{array}{r}6 \\
11 \\
6 \\
6 \\
6 \\
3 \\
0 \\
2\end{array}$ & $\begin{array}{r}(15) \\
(27) \\
(15) \\
(15) \\
(15) \\
(7) \\
(0) \\
(5)\end{array}$ & $\begin{array}{l}35 \\
46 \\
21 \\
27 \\
25 \\
47 \\
10 \\
12\end{array}$ & $\begin{array}{r}(14) \\
(19) \\
(9) \\
(11) \\
(10) \\
(19) \\
(4) \\
(5)\end{array}$ & $\begin{array}{r}8 \\
24 \\
4 \\
5 \\
16 \\
8 \\
5 \\
7\end{array}$ & $\begin{array}{r}(10) \\
(30) \\
(5) \\
(6) \\
(20) \\
(10) \\
(6) \\
(9)\end{array}$ \\
\hline
\end{tabular}

a DR3p, 4p, 3m and $4 \mathrm{~m}$ refer to DR antigens inherited from the father and from the mother, respectively. The distribution of DR4p/3m and DR3p/4m genotypes among DR3, 4 positive index cases ( 81 of $130=62 \%$ and 49 of $130=38 \%$, respectively) differs significantly from the expected ratio of $50 \%(p<0.01)$

ever, in 18 simplex families none of the unaffected siblings was available for HLA-typing. Thus, a total of 287 index cases, 41 secondary affected siblings and 228 unaffected siblings were analysed, including material from a partially analysed preliminary study [19].

In order to obtain results from an independent sample, we also analysed the data of the 5th Genetic Analysis Workshop (GAW 5) [20] contributed by 11 centres in Europe and the United States which provided 80 Caucasian Type 1 diabetic multiplex families without affected parents. Since the results from the GAW 5 and the Herold series were very similar, both series were pooled in order to improve statistical power.

Typing for HLA-A, B, C, DR antigens to determine haplotypes and genotypes was performed by standard microlymphocytotoxicity methods, using sera from the 7 th and 8 th Histocompatibility Workshops; the allotypes of complement factors $\mathrm{Bf}, \mathrm{C} 4 \mathrm{~A}$ and $\mathrm{C} 4 \mathrm{~B}$ were determined as described previously [21]. Only families in which the parental haplotypes could be unambiguously deduced have been included. HLA-DR3 and DR4 antigens of paternal or maternal origin are referred to as $\mathrm{DR} 3 \mathrm{p}, \mathrm{DR} 3 \mathrm{~m}, \mathrm{DR} 4 \mathrm{p}$ and $\mathrm{DR} 4 \mathrm{~m}$, respectively. Genotypes are designated DR $3 p / 4 m$ and DR $4 p / 3 m$ with the slash separating antigens inherited from the father $(p)$ and from the mother $(\mathrm{m})$. If the parental origin is not considered the phenotypes are denoted DR3,4. The distribution of the different parental DR antigens and corresponding genotypes among index cases, affected and unaffected siblings has been compared to that expected in the case of random segregation.

A second aim of the study was to provide risk estimates for developing diabetes in siblings while taking into account the effect of different parental DR antigens. They were calculated as the probability of a sibling being affected given his/her DR phenotype $(\mathrm{DR} 3,4)$, DR genotype (DR4p/3m or DR3p/4m) and haplotype sharing status (2,1 or 0 haplotypes shared with the index case), using Bayes formula. This evaluation was only carried out in the Herold series, since no comparable group of unaffected siblings was available for the GAW 5 affected siblings. An overall empirical risk for siblings of $3 \%$ at age 20 years was used for the calculations. This risk estimate, based on a large family survey of 1930 patients without affected parents, treated at the Herold Hospital [22], is comparable to estimates obtained by other investigators [23, 24].

\section{Statistical analysis}

Distributions of parental DR antigens and corresponding genotypes were compared to those expected in the case of random segregation using Chi square tests, Yates corrections and Fisher's exact test. Comparing affected and unaffected siblings, the relative risk (RR) was calculated using cross-product ratios in $2 \times 2$ tables [9].

\section{Results}

The DR3, DR4 phenotype and genotype distributions among the index cases of the Herold series (simplex and multiplex families) and the GAW 5 series (multiplex families) are shown in Table 1. In the whole group, 35\% (130 of 367) bore both DR3 and DR4, the proportion being slightly, but not significantly, greater among multiplex compared with simplex families.

Among the DR3,4 positive index cases, the DR3 and DR4 antigens of paternal and maternal origin were not distributed randomly: $62 \%$ (81 of 130 ) had inherited DR4 from the father and DR3 from the mother (DR4p/3m) and $38 \%$ (49 of 130), DR3 from the father and DR4 from the mother (DR3p/4m). This distribution differed significantly from the expected ratio of $50 \%(p<0.01)$; but, the distortion was more marked in multiplex families $(71 \%$ and $29 \%$, respectively, $p<0.01)$ than in simplex families $(57 \%$ vs $43 \%$, respectively, $p>0.05$ ).

In index cases who possessed DR3 or DR4 together with any other DR antigen (DR3, DRx or DR4, DRx), the distribution of paternal and maternal DR3 and DR4 antigens did not differ from random samples.

The analysis, in the Herold Series, of the paternal and maternal haplotypes with respect to class III alleles (Bf, C4A, C4B) showed an excess of maternal B18 and/or $\mathrm{BfF} 1, \mathrm{C} 4 \mathrm{BQO}, \mathrm{DR} 3$ haplotypes among the patients of multiplex families: among 17 multiplex index cases who had inherited a maternal DR3 (DR4/3 and DRX/3 combined), 13 ( $76 \%$ ) possessed this haplotype, while only 3 $(18 \%)$ carried B8, C4AQOC4B1, DR3 and one other (BX) DR3 haplotype. A similar distribution was observed in second affected siblings.

In contrast, in simplex families the maternal DR3 haplotypes of index cases were composed of nearly equal proportions of B18 and B8 haplotypes (37\% and $34 \%$, respectively). Among the paternal DR3 haplotypes, on the other hand, B8 and B18 haplotypes were equally distributed in index cases of both multiplex ( $42 \%$ each) and simplex families ( $36 \%$ and $31 \%$, respectively).

This observation could not be confirmed in the GAW 5 series because there were very few B18, DR3 haplotypes in these families (only 8 in total, 6 of which, however, were maternal in origin); further no complement typing had been done and no simplex families were available.

No difference was observed between the patients of simplex and multiplex families with respect to B15 and complement allotypes of paternal and maternal DR4 haplotypes which were comparable to those described elsewhere [4]. 
A comparable excess of DR4p/3m genotypes such as that seen among the index cases of multiplex families was also observed among the secondary affected siblings of the pooled Herold and GAW 5 series, $44 \%$ (53 of 121) of whom bore DR3, DR4 (Table 2). Of these siblings, $72 \%$ were DR $4 \mathrm{p} / 3 \mathrm{~m}$ and $28 \%$, DR $3 \mathrm{p} / 4 \mathrm{~m}$. This distribution was remarkably similar in both the Herold and the GAW 5 series and differed significantly from the expected ratio of $50 \%(p<0.01)$. A slight but non significant opposite trend was observed among the unaffected siblings where $43 \%$ inherited DR3 from the mother and 57\%, from the father $(p>0.05)$.

Comparing affected and unaffected siblings, the relative risk for DR3,4 positive siblings was $6.9\left(p<10^{-7}\right)$ and among these, their possessing a DR $4 \mathrm{p} / 3 \mathrm{~m}$ genotype conferred an additional relative risk of $3.3(p<0.01)$.

Most of the siblings bearing the DR $4 \mathrm{p} / 3 \mathrm{~m}$ combination shared two haplotypes with the index case: $71 \%$ ( 27 of 38 of the affected and $80 \%$ ( 8 of 10 ) of the unaffected siblings. Hence, sharing two haplotypes did not increase further the relative risk for these siblings (data not shown).

Figure 1 shows the risk for developing diabetes in siblings of diabetic index cases conditional to their possessing a DR3,4 phenotype, a DR4p/3m (4/3) or a DR3p/4m (3/4) genotype and to their being HLA-identical (id.) with the index case.

Since only the Herold Series was included in this evaluation, the differences between the estimates must be considered with caution, due to the small sample size and subsequently large confidence intervals. Nevertheless, pooling with the GAW 5 sample resulted in virtually identical risk values and considerably reduced confidence limits (not shown).

Without any specific information, the overall risk estimate for siblings was $3 \%$ (dotted line). The risk increased to $10 \%$ for DR3,4 positive siblings (Fig. $1 \mathrm{~A}$ ). If the parental origin of these antigens was also considered, siblings bearing DR4p/3m $(17 \%)$ had more than a three-fold increase in risk, than for those with DR3p/4m $(5 \%$, $p<0.05)$. The risk for siblings who possessed the DR4p/3m genotype was the same when they also shared both haplotypes with the index case. If the risk is computed in a different order, i.e. starting with the haplotype sharing status and followed by the DR type (Fig.1B), we obtain a risk of $8 \%$ for siblings who are HLA-identical to

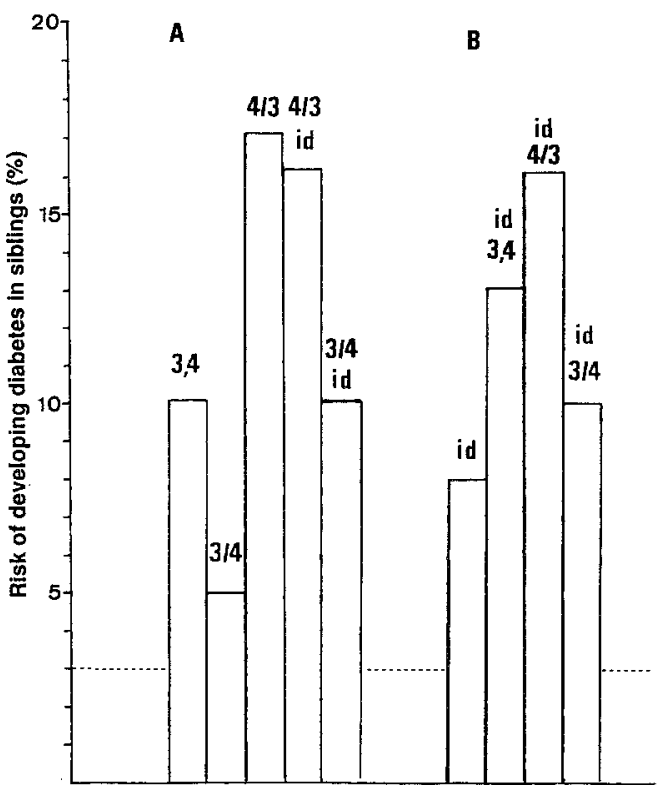

Fig. 1A, B. The risk for developing Type 1 insulin-dependent diabetes in siblings was estimated using Bayes formula to calculate the probability of a sibling being affected conditional to his/her parental DR antigens and/or the number of haplotypes shared with the index case. The overall risk estimate for siblings, $3 \%$ at age 20 , represented by the dotted line, has been estimated on the basis of the Herold Hospital records [2]. 3,4 = DR3,4 positive siblings without distinction of parental origin; $4 / 3=\mathrm{DR} 4 \mathrm{p}$ (inherited from the father), DR3m (inherited from the mother); $3 / 4=D R 3 p$ (inherited from the father), DR4m (inherited from the mother); id. = HLA identical to the index case (two haplotypes shared). A (left panel): The conditional events have been computed in the following order: 1. DR phenotype $(3,4) ; 2$. parental DR antigens $(4 / 3$ or $3 / 4)$; and 3 . parental DR antigens and two shared haplotypes ( $4 / 3$ id. or $3 / 4$ id.). B (right panel): The sequence of the events is: 1 . two shared haplotypes (id.);2. two shared haplotypes and DR phenotype (id. 3,4); and 3. two shared haplotypes and parental DR antigens (id. $4 / 3$ or id. $3 / 4$ )

the index case (risk estimates for siblings sharing 1 or 0 haplotypes were $2 \%$ and $0.6 \%$, respectively; not shown). Having the DR3,4 phenotype and even more so the DR4p/3m genotype added substantially to the risk incurred by identical siblings (a risk of $13 \%$ and $16 \%$, respectively).

A number of clinical parameters were examined in relation to the DR3,4 genotypes in order to assess whether

Table 2. Distribution of paternal and maternal DR3, DR4, antigens among affected and unaffected DR3, DR4 positive siblings of Type 1 insulin-dependent diabetic index cases

\begin{tabular}{|c|c|c|c|c|c|c|c|c|c|}
\hline & \multicolumn{6}{|c|}{ Affected siblings } & \multirow{2}{*}{\multicolumn{3}{|c|}{$\begin{array}{l}\text { Unaffected siblings } \\
\text { Herold series } \\
n=228\end{array}$}} \\
\hline & \multicolumn{2}{|c|}{$\begin{array}{l}\text { Herold series } \\
n=41\end{array}$} & \multicolumn{2}{|c|}{$\begin{array}{l}\text { GAW } 5 \text { series } \\
n=80\end{array}$} & \multicolumn{2}{|c|}{$\begin{array}{l}\text { Pooled sample } \\
n=121\end{array}$} & & & \\
\hline & $n$ & $\%$ & $n$ & $\%$ & $\bar{n}$ & $\%$ & $\bar{n}$ & $\%$ & \\
\hline DR3,4 positive & 17 & (41) & 36 & (45) & 53 & (44) & 23 & $(10)$ & \\
\hline $\begin{array}{l}\text { DR3p/4m } \\
D R 4 p / 3 m\end{array}$ & $\begin{array}{r}5 / 17 \\
12 / 17\end{array}$ & $\begin{array}{l}(29) \\
(71)\end{array}$ & $\begin{array}{l}10 / 36 \\
26 / 36\end{array}$ & $\begin{array}{l}(28) \\
(72)\end{array}$ & $\begin{array}{l}15 / 53 \\
38 / 53\end{array}$ & $\begin{array}{l}(28) \\
(72)\end{array}$ & $\begin{array}{l}13 / 23 \\
10 / 23\end{array}$ & $\begin{array}{l}(57) \\
(43)\end{array}$ & $\begin{array}{l}\text { Expected } \\
50 \% \\
50 \%\end{array}$ \\
\hline
\end{tabular}

DR3p, 4p, 3m and 4m: as in Table 1. Among the affected siblings, the distribution of DR3p/4m and DR4p/3m genotypes differs significantly from the expected ratio ( $50 \%$ each) $(p<0.01)$. It is not different from random in unaffected siblings.

Comparing affected and unaffected siblings, the relative risk for DR3,4 positive sibs is $6.9\left(p<10^{-7}\right)$ and among these, the additional relative risk for DR $4 \mathrm{p} / 3 \mathrm{~m}$ is $3.3(p<0.01)$ 
Table 3. Transmission of DR3 and DR4 from non-diabetic heterozygous parents (Herold Series), to their diabetic and non-diabetic offspring

\begin{tabular}{|c|c|c|c|c|c|}
\hline & \multicolumn{2}{|l|}{ Fathers } & \multicolumn{3}{|l|}{ Mothers } \\
\hline & $\begin{array}{l}\text { DR3 } \\
n=101\end{array}$ & $\begin{array}{l}\text { DR4 } \\
n=137\end{array}$ & $\begin{array}{l}\text { DR3 } \\
n=133\end{array}$ & $\begin{array}{l}\text { DR4 } \\
n=138\end{array}$ & $p$ \\
\hline \multicolumn{6}{|l|}{ Transmitted to } \\
\hline $\begin{array}{l}\text { Diabetic } \\
\text { offspring }\end{array}$ & $\begin{array}{l}81 / 116 \\
(70 \%)\end{array}$ & $\begin{array}{l}119 / 161 \\
(74 \%)\end{array}$ & $\begin{array}{l}126 / 166 \\
(76 \%)\end{array}$ & $\begin{array}{l}120 / 153 \\
(78 \%)\end{array}$ & $>0.05$ \\
\hline $\begin{array}{l}\text { Non-diabetic } \\
\text { offspring }\end{array}$ & $\begin{array}{l}70 / 132 \\
(53 \%)\end{array}$ & $\begin{array}{l}89 / 175 \\
(51 \%)\end{array}$ & $\begin{array}{l}76 / 172 \\
(44 \%)\end{array}$ & $\begin{array}{l}111 / 196 \\
(57 \%)\end{array}$ & $>0.05$ \\
\hline
\end{tabular}

clinical heterogeneity could have influenced the results. However, no difference was found between DR3p/4m and $\mathrm{DR} 4 \mathrm{p} / 3 \mathrm{~m}$ patients with respect to sex, age at onset or severity of the disease, either in first or in secondary affected siblings. Further, the current ages of non-affected siblings and the length of time that the family had been followed up since onset of diabetes were no different (results not shown).

Mean family size was similar in families of DR3 positive fathers and mothers (3.11 and 3.01 children per parent) and in those of DR4 positive fathers and mothers (3.03 and 2.89, respectively), and there were no differences between the recorded numbers of abortions or stillbirths. However, as expected from the observed data, multiplex families had a higher number of DR3 positive mothers and DR4 positive fathers $(p<0.05)$.

In order to detect a possible distortion in the segregation of paternal or maternal DR3 or DR4 haplotypes in the offspring of the Type 1 diabetic families, we investigated the transmission of DR3 and DR4 from non-affected heterozygous parents to their diabetic and nondiabetic children (Table 3). As expected in a disease associated with these markers, both parents transmitted DR3 and DR4 to a majority of their diabetic offspring. These proportions differed significantly from the $50 \%$ ratio expected in the case of random segregation $(p<0.01)$. However, there were no significant differences $(p>0.05)$ between the proportions of DR3 and DR4 transmitted from either fathers or mothers. On the other hand, the proportions of DR3 and DR4 transmitted from the father or mother, respectively, to their non-diabetic offspring were no different from the expected ratio of $50 \%(p>0.05)$.

\section{Discussion}

In our study we show that Type 1 diabetic patients who possess both DR3 and DR4 and whose parents are unaffected, more often share DR3 with their mother and DR4 with their father than can be expected by chance. This implies that, in addition to the previously reported higher risk for diabetes in siblings who are HLA-identical to their diabetic sibling and/or possess the heterozygous DR3, DR4 phenotype $[1-9,25]$, the risk in DR3, DR4 positive siblings is further increased by a DR3 inherited from the mother and a DR4 from the father.
This finding suggests that either a maternal factor, associated with DR3, or a paternal factor associated with DR4, may be involved in the aetiology of Type 1 diabetes. Since it does not occur in all DR3, DR4 positive patients it is probably not a primary event, necessary for the development of diabetes, but more likely a modifying or enhancing event increasing the penetrance of the disease.

The putative event requires, in addition, the presence of both a maternal DR3 and a paternal DR4, since it is not observed in patients possessing either DR3 or DR4 combined with other (DRx) antigens. This could possibly be a consequence of the strong association between Type 1 diabetes and the DR3, DR4 heterozygous state $[2-4,6]$, not observed for other DR3 and DR4 phenotypes. Thus, in DR3, DRX and DR4, DRX phenotypes, a secondary enhancing event may not become visible. Alternatively, it could mean that specific interaction between DR3 and DR4 (or the associated disease genes) causes increased susceptibility especially when DR3 is shared with the mother and DR4 with the father.

Since in DR3,4 positive individuals an increase in maternal DR3 is accompanied by an increase in paternal DR4, and vice versa, either a DR3 related maternal or a DR4 related paternal factor could be primarily responsible for the DR4p/3m excess. Although the hypothesis of a maternal event (presumably during pregnancy) seems biologically more attractive, the possible involvement of the paternal DR4 can be proposed on the basis of two still poorly understood aspects of the inheritance of Type 1 diabetes: (1) the increased transmission of DR4 from diabetic parents to their diabetic offspring $[16,17]$ which may be explained by a dominant transmission of the DR4associated susceptibility factor; (2) the increased risk for diabetes in offspring of diabetic fathers compared with that of diabetic mothers $[26,27]$. Overtransmission of a dominant, DR4 associated predisposing allele from diabetic fathers could indeed explain a higher occurrence of diabetes in their offspring, namely in those who have in addition received DR 3 from the mother. However, this interpretation does not account for the present observations since all families with affected parents were excluded from our analysis.

An apparent overtransmission of DR4 from fathers to affected offspring may eventually result from the inclusion of a high percentage of multiplex families, which are more likely to have DR3, DR4 children, in the study population. Overtransmission of DR4 from non-diabetic fathers to both diabetic and non-diabetic offspring has also been claimed [28] but reports from several investigators $[16,29-31]$ as well as our own data, have failed to show any significant differences of transmission between parents. On the other hand, the overtransmission reported for paternal [32] or maternal [33] A1B8 (DR3) haplotypes related to the sex of the offspring in diabetic and healthy families still remains to be confirmed.

In contrast, if we hypothesize that interaction between DR4 and a DR3-associated maternal event results in increased susceptibility for Type 1 diabetes in the offspring, we should expect a selective increase of the DR4p/DR3m pattern in the affected siblings and a secondary increase of DR4 positive fathers and of DR3 positive mothers inde- 
pendently of their being affected, as is observed in our study.

The possible role of additional genetic factors, e.g. in the class III region, cannot be ruled out in view of the observation that a majority of the DR3 haplotypes that the patients in multiplex families had inherited from their mother, at least in the Herold Series, were B18 and/or C4BQO positive. This haplotype shows in the French population much stronger association with Type 1 diabetes than the B8, DR3 haplotype [4] and is characteristic of a particularly early-onset form [34]. It seems plausible that those factors involved in early onset - possibly C4BQO and/or other complement factors - could also increase the familial penetrance of the disease. The observation that the first diabetic child in multiplex families is generally affected at an earlier age than in simplex families [35] is in keeping with this hypothesis. Nevertheless, the preferential maternal transmission of the responsible factor(s) still requires explanation. Mechanisms controlling zygotic assortment at a gametic or post-zygotic stage could probably lead to disturbances in the inheritance of certain haplotypes; however, these mechanisms are at present poorly understood.

We believe that a mechanism implicating interaction in utero between mother and fetus is the hypothesis which could best account for the observed data.

Experimental evidence in mice has shown that materno-fetal interaction [36] or immune manipulation at birth [37] can influence the future immune repertoire and induce allogeneic tolerance in the offspring. It has also been reported that the ability to develop either autoantibodies or self-tolerance later in life depends on the moment during fetal life at which the fetus has been exposed to the autoantigen [38].

An alternative mechanism could be the initiation of Beta cell lesion or anti-Beta cell autoimmunity by intrauterine exposure to some triggering event, such as viral or toxic agents, restricted by DR3. Diabetes in children with congenital rubella is a model of fetal viral infection causing Type 1 diabetes after a long latency period which is associated in most cases with DR3 [39].

Other common infections may have comparable effects. The increased incidence of the observed phenomenon among multiple affected siblings favours the hypothesis of a virus persistent in the mother and reactivated during successive pregnancies. Latent cytomegalovirus (CMV) infection, frequently found in pregnant women and neonates would be a possible candidate. In this respect, recent observations concerning the presence of CMV genome in lymphocytes of diabetic patients are particularly interesting [40]. Autoimmune development is favoured by delayed clearance of the virus [41] which may be related to the low response to various viral antigens associated with DR3 [42]. Sharing DR3 with the mother while possessing DR4 may play a crucial role in the presentation/recognition of an antigen during fetal life or the regulation of the immune response after birth.

Even though these hypotheses remain speculative, the finding described has important implications for risk prediction in siblings. The risk is at a maximum in the case of a DR4p/DR3m genotype and it is much higher than the risk predicted by HLA identity with a diabetic patient.

Our observations add a new piece to the puzzle of heterogeneity of Type 1 diabetes which should be taken into account in future models of inheritance.

Acknowledgements. This work was supported by grants from the Aide aux Jeunes Diabétiques, INSERM C.R.E. 888006, INSERMCNAMTS 62789411 and the Ministère de la Recherche et de l'Industrie $83 \mathrm{C} 0284$. We are indebted to Dr. M. Montes de Oca for revision of the manuscript.

\section{References}

1. Svejgaard A, Platz P, Ryder LP (1980) Insulin-dependent diabetes mellitus. Joint report. In: Terasaki PI (ed) Histocompatibility testing. UCLA, Los Angeles, pp 1638-1656

2. Platz P, Jacobsen BK, Morling N, Ryder LP, Svejgaard A, Thomsen M, Christy M, Kromann H, Benn J, Nerup J, Green A, Hauge M (1981) HLA-D and -DR antigens in genetic analysis of insulin-dependent diabetes mellitus. Diabetologia 21: 108-115

3. Deschamps I, Lestradet H, Bonaiti C, Schmid M, Busson M, Benajam A, Marcelli-Barge A, Hors J (1980) HLA genotype studies in juvenile insulin-dependent diabetes. Diabetologia 19: 189-193

4. Deschamps I, Marcelli-Barge A, Lallemand N, Poirier JC, Bochu V, Prevost P, Busson M, Masset M, Lestradet H, Hors J (1988) Studies of cis and trans interactions between extended HLA-haplotypes in insulin-dependent diabetes. Tissue Antigens 31:259-269

5. Anderson CE, Hodge SE, Rubin R, Rotter JI, Terasaki PI, Irvine WJ, Rimoin DL (1983) A search for heterogeneity in insulin-dependent diabetes mellitus: HLA and autoimmune studies in simplex, multiplex and multi-generational families. Metabolism 32: 471-477

6. Svejgaard A, Jakobsen BK, Platz P, Nerup J, Christy M, BorchJohnsen K, Parving HH, Deckert T, Molsted-Pedersen L, Kühl C, Buschard K, Green A (1986) HLA associations in insulin-dependent diabetes: search for heterozineity in different groups of patients from a homogeneous population. Tissue Antigens 28: 237-244

7. Tarn AC, Dean BM, Schwarz G, Thomas JM, Ingram D, Bottazzo GF, Gale EAM (1988) Predicting insulin-dependent diabetes. Lancet I: $845-850$

8. Deschamps I, Lestradet H, Marcelli-Barge A, Poirier JC, Cohen D, Hors J (1986) Facteurs de risque du diabète insulinodépendant. Path Biol 34: 767-772

9. Svejgaard A, Platz P, Ryder LP, Staub-Nielsen L, Thomsen M (1975) HLA and disease associations. A survey. Transplant Rev $22: 3-43$

10. Hodge SE, Rotter JI, Lange KL (1980) A three allele model for heterogeneity of juvenile-onset insulin-dependent diabetes. Ann Hum Genet Lond 43: 399-409

11. Bertrams J, Baur MP (1984) Insulin-dependent diabetes mellitus. In: Albert ED, Baur MP, Mayr WR (eds) Histocompatibility testing (1984). Springer, Berlin Heidelberg New York, pp 348358

12. Clerget-Darpoux F, Dizier MH, Bonaiti-Pellie C, Babron MC, Hochez J, Martinez M (1986) Discrimination between genetic models for insulin-dependent diabetes mellitus. Genet Epidemiol [Suppl] 1: 313-318

13. Baur MP (1986) Genetic analysis workshop IV: Insulin-dependent diabetes mellitus. Summary. Gen Epidemiol [Suppl] 1:299. 312

14. Todd JA, Acha-Orbea H, Bell JI, Chao N, Fronek Z, Jacob CO, Mc Dermott M, Sinha AA, Timmerman L, Steinman L, Mc De- 
vitt HO (1988) A molecular basis for MHC class II. Associated autoimmunity. Science 240: 1003-1009

15. Rotter JI, Vadheim CM, Petersen GM, Cantor RM, Riley WJ, MacLaren NK (1986) HLA haplotype sharing and proband genotype in Type I diabetes. Genet Epidemiol [Suppl] 1:347-352

16. MacDonald MJ, Gottschall J, Hunter JB, Winter KL (1986) HLA-DR4 in insulin-dependent diabetic parents and their diabetic offspring: a clue to dominant inheritance. Proc Natl Acad Sci USA 83: 7049-7053

17. Clerget-Darpoux F, Babron MC, Prum B, Lathrop M, Deschamps I, Hors J (1988) A new method to test genetic models in HLA associated diseases: the MASC method. Ann Hum Gent 52: 247-258

18. Thomson G, Robinson WP, Kuhner MK, Joe S, Mac Donald MJ, Gottschall JC, Barbosa J, Rich SS, Bertrams J, Baur MP, Partanen J, Tait BD, Schober E, Mayr WR, Ludvigsson J, Lindblom B, Farid NR, Thompson C, Deschamps I (1988) Genetic heterogeneity, modes of inheritance and risk estimates for a joint study of Caucasians with insulin-dependent diabetes mellitus. Am J Hum Genet 43: 799-816

19. Deschamps I, Hors J, Clerget-Darpoux F, Marcelli-Barge A, Lestradet H, Dausset J (1988) Risque accru de diabète insulinodépendant pour les germains d'enfants diabétiques ayant reçu l'haplotype DR3 de la mère. CR Acad Sci (Paris) 308 (Série III): 501-506

20. Clerget-Darpoux F, MacCluer J, Falk C (eds) (1989) Genetic analysis of complex traits. A: insulin-dependent diabetes. Genet Epidermiol 6: 1-160

21. Marcelli-Barge A, Poirier JC, Schmid M, Deschamps I, Lestradet $H$, Prevost $\mathbf{P}$, Hors J (1984) Genetic polymorphism of the fourth component of complement and Type I (insulin-dependent) diabetes. Diabetologia 27: 116-121

22. Lestradet H, Battistelli F, Combier E, Giron BJ (1974) L'hérédité du diabète insulinodépendant. Nouv Presse Médicale 3: $1077-1080$

23. Wagener DK, Sacks JM, Laporte RE, MacGregor JM (1982) The Pittsburgh study of insulin-dependent diabetes mellitus. Risk for diabetes among relatives of Type 1 diabetes. Diabetes 31: 136-144

24. Tillil H, Köbberling J (1987) Age corrected empirical genetic risk estimates for first degree relatives of Type I diabetes patients. Diabetes 36: 93-99

25. Cavender DE, Wagener DK, Rabin BS, Becker DJ, Orchard TJ, Eberhardt MS, Laporte RE, Drash AL, Kuller LH (1984) The Pittsburgh insulin-dependent diabetes mellitus study. HLA antigens and haplotypes as risk factors for the development of Type I diabetes in Type I diabetes patients and their siblings. J Chron Dis 37: 555-568

26. Warram JH, Krolewski AS, Gottlieb MS, Kahn CR (1984) Differences in risk of insulin-dependent diabetes in offspring of diabetic mothers and diabetic fathers. N Engl J Med 311:149-152

27. Warram JH, Krolewski AS, Kahn R (1988) Determinants of Type I diabetes and perinatal mortality in children of diabetic mothers. Diabetes 37: 1328-1334

28. Vadheim CM, Rotter JI, MacLaren NK, Riley WJ, Anderson EA (1986) Preferential transmission of diabetic alleles within the HLA gene complex. N Engl J Med 315: 1314-1318

29. Falk CT, Field LL, Hodge SE (1987) Transmission of diabetic alleles within the HLA complex. N Engl J Med 317:768 (Letter)
30. Bertrams J, Kuglin B (1988) No segregation distortion for HLA genes in Type 1 (insulin-dependent) diabetes. Diabetologia 31: 470 (Abstract)

31. Thivolet $\mathrm{C}$, Beaufrère $\mathrm{B}$, Betuel $\mathrm{H}$, Gebuhrer L, Chatelain $\mathrm{P}$, Durand A, Tourniaire J, François R (1988) Islet cell and insulin antibodies in subjects at high risk for development of Type 1 (insulin-dependent) diabetes mellitus: the Lyon family study. Diabetologia 31: 741-746

32. Cudworth AG, Gorsuch AN, Wolf E, Festenstein H (1979) A new look at HLA genetics with particular reference to Type 1 diabetes. Lancet II: 389-391

33. Marcelli-Barge A, Deschamps I, Poirier JC, Hors J (1986) Distorsion de la ségrégation maternelle des allèles silencieux du facteur 4 du complément dans des familles normales et des familles diabétiques. CR Acad Sci (Paris) 303 (Série III): 551-556

34. Deschamps I, Marcelli-Barge A, Poirier JC, Cohen-Haguenauer O, Abderrahim H, Cohen D, Lestradet H, Hors J (1988) Two distinct HLA-DR3 haplotypes are associated with age related heterogeneity in Type 1 (insulin-dependent) diabetes. Diabetologia 31: 896-901

35. Deschamps I, Lestradet H, Busson M, Hors J (1984) Evaluation of recurrence risk in siblings of diabetic children: importance of age and birth order in relation to HLA genotypes. Diab Res 1: $125-130$

36. Bona CA, Victor C (1984) Ontogeny of antilevan and insulin antibody responses. In: Köhler H, Urbain J, Cazenave PA (eds) Idiotypy in biology and medicine. Academic Press, Orlando, pp 173-185

37. Bendelac A, Boitard C, Bach JF, Carnaud C (1989) Neonatal induction of allogeneic tolerance prevents T-cell-mediated autoimmunity in NOD mice. Eur J Immunol 19: 611-616

38. Adams TE, Alpert S, Manahan D (1987) Non tolerance and autoantibodies to a transgenic self antigen expressed in pancreatic $B$ cells. Nature (Lond) 325:223-228

39. Rubinstein P, Walker ME, Fedun B, Witt ME, Cooper LZ, Ginsberg-Fellner F (1982) The HLA system in congenital rubella patients with and without diabetes. Diabetes 31: 1088-1091

40. Pak CY, McArthur RG, Eun HM, Yoon JW (1988) Association of cytomegalovirus infection with autoimmune type 1 diabetes. Lancet II: $2-4$

41. Southern P, Oldstone MBA (1983) Medical consequences of persistent viral infection. N Engl J Med 314: 359-367

42. Bruserud $\varnothing$, Stenersen M, Thorsby E (1985) T lymphocyte responses to Coxsackie B4 and mumps virus. II. Immunoregulation by HLA-DR3 and -DR4 associated restriction elements. Tissue Antigens 26: 179-192

Received: 10 October 1989

and in revised form: 14 February 1990

Dr. I. Deschamps

Service Endocrinologie et Diabète de l'Enfant,

Hôpital des Enfants-Malades

149 rue de Sèvres

F-75015 Paris

France 